and the Metropolitan Police for their unfailing co-operation; Dr Eva Alberman for survival rates of infants in England and Wales given in table I; and Dr Ann Stewart for her helpful advice.

Requests for reprints should be addressed to Dr E O R Reynolds, Department of Paediatrics, University College Hospital, London WCl.

\section{References}

' Klaus, M H, and Fanaroff, A A, Care of the High-Risk Neonate. Philadelphia, Saunders, 1973.

Gregory, G A, et al, New England fournal of Medicine, 1971, 284, 1333.

${ }^{3}$ Expert Group on Special Care for Babies, Reports on Public Health and Medical Subjects, No. 127. London, HMSO, 1971.

- Segal, S, Pediatric Clinics of North America, 1966, 13, 1195.

5 Storrs, C N, and Taylor, M R H, British Medical fournal, 1970, 3, 328.

' Segal, S (editor), Transport of the High Risk Newborn. Montreal, Canadian Paediatric Society, 1972.
'Swyer, P R, and Goodwin, J W (editors), Regional Services in Reproductive Medicine. Montreal, Canadian Paediatric Society, 1973.

' Blake, A M, et al, Lancet, 1970, 1, 25.

${ }^{9}$ Reynolds, E O R, International Anesthesiology Clinics, 1974, 12, 259.

1 " Baum, J D, and Scopes, J W, Lancet, 1968, 1, 672.

$"$ Lubchenco, L O, et al, Pediatrics, 1963, 32, 793.

12 Stewart, A L, and Reynolds, E O R, Pediatrics, 1974, 54, 1974.

13 Stahlman, M, et al, Pediatric Clinics of North America, 1973, 20, 433

is Bryan, M H, Levison, H, and Swyer, P R, Bulletin de Physio-Pathologie Respiratoire. 1973, 9, 1587.

15 Fisch, R O, et al, fournal of Pediatrics, 1975, 86, 497

${ }^{16}$ Davies, P A, and Stewart, A L, British Medical Bulletin, 1975, 31, 85

${ }^{17}$ Drillien, C M, Archives of Disease in Childhood, 1958, 33, 10.

18 McDonald, A, Children of Very Low Birth Weight. London, Heinemann, 1967.

19 Cassady, G, in Clinical Perinatology, ed S Aladjem and A K Brown, p 422. St Louis, Mosby, 1974.

20 Manciaux, M, in Perinatal Medicine, ed. H Bossart et al, p 13 Bern, Huber, 1973.

${ }^{21}$ Office of Health Economics. Mental Handicap. London, OHE, 1973.

\title{
Aminocaproic acid and menstrual loss in women using intrauterine devices
}

\author{
J M KASONDE, J BONNAR
}

British Medical fournal, 1975, 4, 17-19

day during menstruation for the subsequent four periods. For the next four periods they took the treatment during cycles 6 and 8 only.

The second group consisted of 35 women presenting with IUD menorrhagia, irrespective of the type of device. These women were studied through six consecutive menstrual collections. The first was a baseline measurement; the next three were treatment periods during which they received $3 \mathrm{~g}$ EACA four times a day taken as a powder dissolved in water. The last two periods were without treatment.

A controlled study of the effect of aminocaproic acid $3 \mathrm{~g}$ six-hourly taken by mouth during menstruation was carried out on 56 women for eight months from the time of insertion of a Lippes $D$ intrauterine device (IUD). Thirty-five women presenting with menorrhagia in association with an IUD were also treated during three out of six consecutive menses. A highly significant reduction in menstrual loss was observed during treatment in both groups.

\section{Introduction}

Excessive menstrual bleeding is the commonest complication of intrauterine contraceptive devices (IUDs) and is responsible for their discontinuance in up to $20 \%$ of users. ${ }^{1-4}$ Since aminocaproic acid (EACA), an antifibrinolytic agent, effectively controls menorrhagia not related to IUDs we have studied its effects on menstrual blood loss in women using IUDs.

\section{Patients and method}

Two groups of women were studied, all of whom gave full and informed consent. The first group consisted of 56 women requesting intrauterine contraception. They had one menstrual collection measured before insertion and eight consecutive collections measured after insertion. The patients were allocated to treatment and control groups matched for pre-insertion menstrual loss and stratified to cover a range of losses from 5 to $100 \mathrm{ml}$ (table I). All were fitted with Lippes D IUDs. The treated women received $3 \mathrm{~g}$ EACA four times a day for seven days from the date of insertion, then $3 \mathrm{~g}$ four times a

Nuffield Department of Obstetrics and Gynaecology, John Radcliffe Hospital, Oxford

J M KASONDE, MRCOG, research fellow

J BONNAR, MD, FRCOG, clinical reader

TABLE I-Pre-insertion blood loss in 56 treated women and controls

\begin{tabular}{|c|c|c|c|}
\hline \multirow{2}{*}{$\begin{array}{l}\text { No. of } \\
\text { Patients }\end{array}$} & \multicolumn{3}{|c|}{ Blood Loss (ml) } \\
\hline & Range & $\begin{array}{c}\text { Treated Women } \\
(\mathbf{n}=\mathbf{2 8})\end{array}$ & Controls $(n=28)$ \\
\hline 16 & $5-20$ & $\begin{array}{r}5 \cdot 4 \\
8 \cdot 7 \\
9 \cdot 0 \\
9 \cdot 2 \\
11 \cdot 8 \\
14 \cdot 2 \\
16 \cdot 9 \\
19 \cdot 8\end{array}$ & $\begin{array}{r}7 \cdot 9 \\
10 \cdot 7 \\
12 \cdot 2 \\
12 \cdot 3 \\
15 \cdot 9 \\
16 \cdot 2 \\
16 \cdot 6 \\
17 \cdot 6\end{array}$ \\
\hline 16 & $>20-40$ & $\begin{array}{l}20 \cdot 3 \\
20 \cdot 6 \\
22 \cdot 2 \\
23 \cdot 2 \\
23 \cdot 4 \\
29 \cdot 7 \\
30 \cdot 1 \\
35 \cdot 4\end{array}$ & $\begin{array}{l}20 \cdot 7 \\
21 \cdot 6 \\
24 \cdot 4 \\
25 \cdot 5 \\
26 \cdot 5 \\
29 \cdot 8 \\
30 \cdot 3 \\
33 \cdot 7\end{array}$ \\
\hline 10 & $>40-60$ & $\begin{array}{l}46 \cdot 1 \\
49.6 \\
49.9 \\
53.2 \\
60.0\end{array}$ & $\begin{array}{l}40 \cdot 6 \\
40 \cdot 9 \\
43 \cdot 2 \\
47 \cdot 4 \\
51 \cdot 8\end{array}$ \\
\hline 6 & $>60-80$ & $\begin{array}{l}62.9 \\
63 \cdot 2 \\
67.7\end{array}$ & $\begin{array}{l}64.9 \\
71 \cdot 6 \\
80 \cdot 0\end{array}$ \\
\hline 4 & $>80-100$ & $\begin{array}{l}96.9 \\
99.0\end{array}$ & $\begin{array}{l}84 \cdot 8 \\
87 \cdot 2\end{array}$ \\
\hline 4 & $>100$ & $\begin{array}{l}124 \cdot 7 \\
131 \cdot 3\end{array}$ & $\begin{array}{l}103 \cdot 2 \\
157.4\end{array}$ \\
\hline \multicolumn{2}{|c|}{ Mean } & $43 \cdot 0$ & $42 \cdot 7$ \\
\hline
\end{tabular}

All patients gave a full medical history and underwent clinical examination, including gynaecological assessment.

All tampons and sanitary towels used were collected in polyethylene bags numbered for each day of bleeding. Blood loss was measured by a modified alkaline haematin method. ${ }^{5}$ The pads and tampons were soaked in $5 \%$ sodium hydroxide for $\mathbf{4 8}$ hours. The 
TABLE II-Mean menstrual blood loss $(m l) \pm S D$ before and after Lippes $D I U D$ insertion

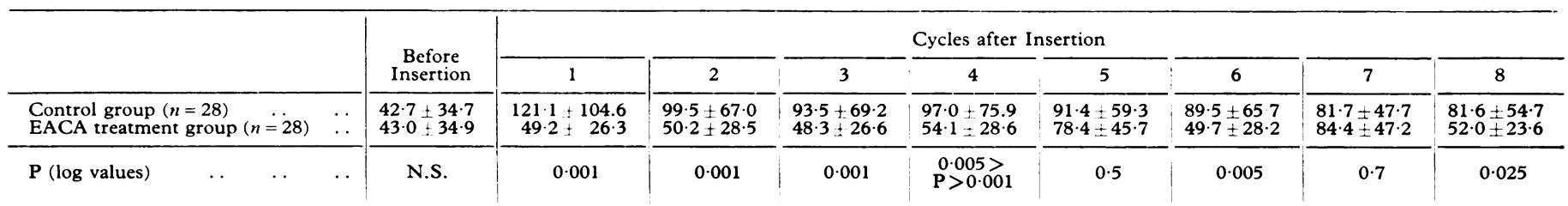

In view of the skewed distribution of menstrual blood loss the original values were converted to logarithms for tests of significance (Student's $t$ test). In cycles 5 and 7 the women in the treatment group received no EACA. The mean losses in these cycles showed no significant difference.

TABLE III-Mean duration of periods (Days) $\pm S D$ before and after insertion of Lippes D IUD

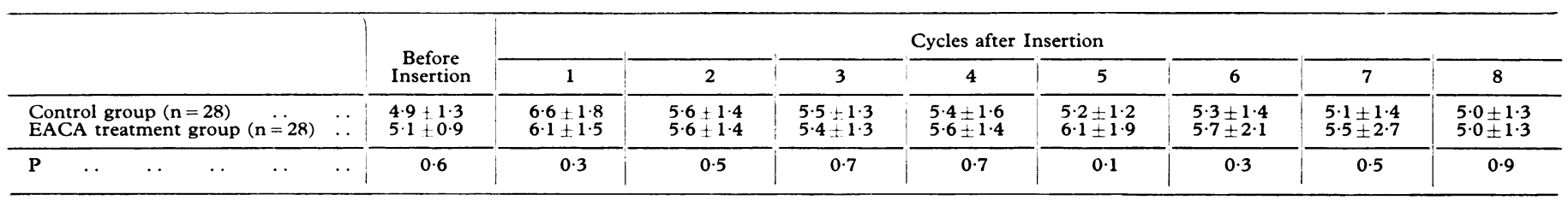

optical density of the resulting solution of alkaline haematin was measured with a Vitatron photometer and compared with the reading obtained from the patient's venous blood mixed with a known volume of $5 \%$ sodium hydroxide. For quality control a known volume of venous blood was placed on a sanitary towel (without the knowledge of the technician) for measurement of blood loss; $5 \mathrm{ml}$ was used on four occasions and the experiment was repeated with 10, 15, and 20 $\mathrm{ml}$. The results of the 16 experiments showed a range of error from $0.5 \%$ to $11.2 \%$ with an average recovery of $97 \%$.

\section{Results}

\section{PROPHYLACTIC STUDY}

Total Blood Loss-The mean pre-insertion blood loss for the 28 women in the untreated group was $42.7 \mathrm{ml}$, while for the treated group it was $43.0 \mathrm{ml}$ (table II). After insertion of the IUD the menstrual loss for the control group rose to a mean of $121.1 \mathrm{ml}$, decreasing to $81.6 \mathrm{ml}$ by the eighth post-insertion period. By contrast the treated group showed a slight rise to $54.1 \mathrm{ml}$, falling only slightly with time, except for the two non-treatment cycles, when the blood loss rose to 78.4 and $84.4 \mathrm{ml}$ respectively, which was similar to that in the untreated group. The difference in losses between the EACA group during treatment and the control group was highly significant $(\mathrm{P}<0.001)$.

Duration of Periods-Both the treated and control groups showed a significant increase in the duration of menses after insertion of the IUD $(P<0.005)$ with no significant difference between the groups (table III).

Intermenstrual Bleeding-The number of days on which intermenstrual bleeding ("spotting") occurred was recorded on "menstrual calendar" cards kept by the patients. Altogether 16 women in the treated group and 18 in the control group experienced spotting (table IV). With successive cycles after insertion of the IUD, however, significantly fewer women in the treated group continued to have intermenstrual spotting $(P<0.05)$. Furthermore, the total number of days of spotting was significantly lower in the treated women $(P<0.01$; Wilcoxon's signed rank test).

\section{THERAPEUTIC STUDY}

The 35 women with IUD menorrhagia given EACA had a mean menstrual loss before treatment of $100.4 \mathrm{ml}$ (table V). This was reduced to $41 \cdot 1-49 \cdot 8 \mathrm{ml}$ during treatment, returning to the previous levels when treatment was stopped. The reduction was highly significant $(P<0.001$; Student's $t$ test on logarithmic values).

\section{SIDE EFFECTS}

In $49(77.8 \%)$ of the 63 women taking EACA mild to moderate side effects occurred. The commonest were nausea, headache, and dizzi- ness. The following three patients were unable to continue the trial because of side effects.

Case 1-A 31-year-old para-1 had nausea but not vomiting during the first treatment period, which lasted five days, and in view of this she discontinued treatment.

Case 2-A 32-year-old para-2 experienced severe nausea followed by vomiting and headache on the third day of the fourth cycle of treatment with EACA. She also complained of dizziness to the extent of losing her balance, and treatment was stopped.

Case 3-A 36-year-old para-1 developed gross oedema of the legs and face on the third day of treatment with EACA. Biochemical tests of renal function gave normal results and venography showed no abnormality of the venous system in the lower limbs. An allergic type of reaction was suspected. After a year she still had bilateral leg oedema. A cause-effect relationship with her EACA treatment was not established and we are not aware of any previous report of this complication.

TABLE IV-Incidence of intermenstrual bleeding in the EACA-treated women and controls

\begin{tabular}{|c|c|c|c|c|c|c|c|c|}
\hline \multirow{2}{*}{\multicolumn{3}{|c|}{$\begin{array}{c}\text { Cycles } \\
\text { after } \\
\text { Insertion }\end{array}$}} & \multicolumn{3}{|c|}{ EACA Group $(n=28)$} & \multicolumn{3}{|c|}{ Control Group $(n=28)$} \\
\hline & & & $\begin{array}{l}\text { No. of } \\
\text { Women }\end{array}$ & $\begin{array}{l}\text { No. of } \\
\text { Days }\end{array}$ & $\begin{array}{c}\text { Women- } \\
\text { Days }\end{array}$ & $\begin{array}{c}\text { No. of } \\
\text { Women }\end{array}$ & $\begin{array}{l}\text { No. of } \\
\text { Days }\end{array}$ & $\begin{array}{c}\text { Women- } \\
\text { Days }\end{array}$ \\
\hline Insertion & $\begin{array}{l}-1 \\
1-2 \\
2-3 \\
3-4 \\
4-5 \\
5-6 \\
6-7 \\
7-8\end{array}$ & $\begin{array}{l}. \\
\cdots \\
\cdots \\
\cdots \\
\cdots \\
\cdots\end{array}$ & $\begin{array}{r}16 \\
12 \\
12 \\
9 \\
8 \\
5 \\
4 \\
3\end{array}$ & $\begin{array}{r}81 \\
30 \\
37 \\
33 \\
35 \\
8 \\
18 \\
14\end{array}$ & $\begin{array}{r}1296 \\
360 \\
444 \\
297 \\
280 \\
40 \\
72 \\
42\end{array}$ & $\begin{array}{r}18 \\
15 \\
10 \\
11 \\
11 \\
8 \\
10 \\
10\end{array}$ & $\begin{array}{l}90 \\
61 \\
44 \\
48 \\
37 \\
39 \\
32 \\
39\end{array}$ & $\begin{array}{r}1620 \\
915 \\
440 \\
528 \\
407 \\
312 \\
320 \\
390\end{array}$ \\
\hline Total & & $\ldots$ & & 256 & 2831 & & 390 & 4932 \\
\hline
\end{tabular}

Differences between the two groups of women were significant for numbers with intermenstrual bleeding $(P<0.05)$ and numbers of days of intermenstrual bleeding intermenst $\mathrm{P}<0.01)$.

TABLE v-Fall in menstrual blood loss (ml) with EACA in 35 women using various IUCDs*

\begin{tabular}{|c|c|c|c|c|c|c|}
\hline \multirow{2}{*}{$\begin{array}{l}\text { Cycle after } \\
\text { Insertion }\end{array}$} & \multirow[b]{2}{*}{1} & \multicolumn{3}{|c|}{ EACA Treatment } & \multirow[b]{2}{*}{5} & \multirow[b]{2}{*}{6} \\
\hline & & 2 & 3 & 4 & & \\
\hline $\begin{array}{lcc}\text { Arithmetic } & \text { mean } \\
\text { SD } & . . & \ldots \\
\text { SE } & . & \ldots\end{array}$ & $\begin{array}{r}100 \cdot 4 \\
66 \cdot 8 \\
11.3\end{array}$ & $\begin{array}{r}41 \cdot 1 \\
33 \cdot 5 \\
5 \cdot 7\end{array}$ & $\begin{array}{r}48 \cdot 4 \\
38 \cdot 4 \\
6 \cdot 5\end{array}$ & $\begin{array}{r}49 \cdot 8 \\
44 \cdot 5 \\
7 \cdot 5\end{array}$ & $\begin{array}{l}90 \cdot 5 \\
71 \cdot 5 \\
12 \cdot 1\end{array}$ & $\begin{array}{r}83 \cdot 6 \\
53 \cdot 8 \\
9 \cdot 1\end{array}$ \\
\hline
\end{tabular}

* Lippes D (3 women), Saf-T-coil (23), Dalkon shield (6), Copper 7 (3).

Significance of reduction in blood loss $P<0.001$ (Student's $t$ test with logarithmic transformation of individual values).

\section{Discussion}

A role for fibrinolysis in the pathogenesis of menorrhagia was first suggested by Whitehouse, ${ }^{6}$ and other workers subsequently 
produced confirmatory evidence. ${ }^{7}$ The relevance of endometrial fibrinolysis to IUD menorrhagia was suggested by finding high fibrinolytic activity around IUDs removed from women with excessive bleeding. ${ }^{8}$ The use of EACA in the treatment of IUD menorrhagia therefore has a rational basis. Our results show that EACA reduces menstrual blood loss in women using IUDs. This effect is limited to the days of treatment and no carry-over to the next period was found. The duration of periods does not appear to be affected. A steady rise in the menstrual loss during treatment periods appeared to be due to failure to maintain adequate dosage in successive periods.

We concluded that EACA is effective in controlling IUD menorrhagia and that intermenstrual bleeding is reduced.

We thank Mr John Guillebaud for co-operation. We are grateful to Miss E Thomas and Mrs G Guillebaud for nursing help, and to Misses E Johnston, D Ayres, and G Danks for technical work.

This study was made possible by financial help from the Ford
Foundation, the International Planned Parenthood Federation, and the University of Zambia. KABI supplied the EACA and supported Miss Jihnston. Sanitary materials were supplied by Lilia-White Ltd, Bonts I.td, and Tampax Ltd.

\section{References}

${ }^{1}$ Lippes, J, American Fournal of Obstetrics and Gynecology, 1965, 93, 1024. Fulton, D I, Hughes, R, and Neely, M R, Fournal of Obstetrics and Gynaecology of the British Commonwealth, i967, 74, 766.

${ }^{3}$ McCulloch, G, Medical fournal of Zambia, 1970, 4, 49.

+ Jones, R W, Parker, A, and Elstein, M, British Medical fournal, 1973, 3, 143.

Hallberg, L, and Nilsson, L, Scandinavian fournal of Clinical and Laboratory Investigation, 1964, 16, 244.

${ }^{6}$ Whitehouse, H B, Lancet, 1914, 1, 877

Rybo, G, Acta Obstetricia et Gynecologica Scandinavica, 1966, 45, 429.

$\checkmark$ Bonnar, J, and Allington, M, Paper read at VIII World Congress on Fertility and Sterility, Buenos Aires, Argentina, 5 November 1974.

\title{
Vitamin E deficiency and platelet functional defect in a jaundiced infant
}

\author{
M. KHURSHID, T. J. LEE, I. R. PEAKE, A. L. BLOOM
}

British Medical fournal, 1975, 4, 19-21

\section{Summary}

A 16-month-old infant with hepatic fibrosis, cholestasis, and chronic jaundice had signs of vitamin $E$ deficiency, including mild acanthocytosis, thrombocytosis, increased peroxide haemolysis, and absent serum vitamin $E$. Abnormal prothrombin consumption and platelet ristocetin aggregation suggested the presence of defective platelet function, and correction studies indicated that this was due to a plasma defect. The abnormality was corrected by treatment with vitamin $E$, and the findings suggest a possible role of this vitamin in platelet reactions.

\section{Introduction}

Little is known about the role of Vitamin $\mathrm{E}$ in thrombo poiesis or platelet function. High platelet counts are a recognized feature of vitamin $\mathrm{E}$ deficiency in premature infants and there is evidence suggesting that vitamin E may play a part in platelet aggregation induced by hydrogen peroxide.' We report here on an infant with hepatic fibrosis and cholestatic jaundice who developed vitamin E deficiency and impaired platelet function.

Department of Haematology, University Hospital of Wales, Cardiff CF4 4XW

M. KHURSHID, M.B., M.R.C.PATH., Senior Registrar (Present address Department of Haematology, Morriston Hospital, Swansea)

I. R. PEAKE, PH.D., Senior Scientific (Officer

A. L. BLOOM, M.D., M.R.C.PATH., Reader in Haematology

Department of Child Health, University Hospital of Wales, Cardiff CF4 4XW

T. J. LEE, M.B., M.R.C.P., Senior House Officer (Present address: Hospital for Sick Children, Great Ormond Street, London)

\section{Case Report}

A male infant weighing $3.55 \mathrm{~kg}$ was born by forceps delivery in May 1973 after a full-term pregnancy. The haemoglobin level at birth was $20.5 \mathrm{~g} / \mathrm{dl}$; his blood group was $\mathrm{B}+$; and the direct antiglobulin test on cord blood was negative. The mother was a primigravida, her blood group was $\mathrm{B}-$, but the antibody screen at 32 weeks' pregnancy gave negative results. The only medication received during pregnancy was oral iron.

Clinical examination of the infant at birth showed no abnormality. On day 2 twitching of face and limbs was noted. This subsided without treatment. On day 6 jaundice was noted. The serum bilirubin was $61.5 \mu \mathrm{mol} / 1,(3.6 \mathrm{mg} / 100 \mathrm{ml})$, serum aspartate aminotransferase (SGOT) $38 \mathrm{IU} / 1$, serum alanine amino-transferase (SGPT) $36 \mathrm{IU} / \mathrm{l}$, and serum alkaline phosphatase $55 \mathrm{IU} / 1$. On day 16 he was still jaundiced and the serum bilirubin was $46 \cdot 2 \mu \mathrm{mol} / \mathrm{l}(2.7 \mathrm{mg} / 100 \mathrm{ml})$. The Wasserman reaction and virus agglutination tests were negative. Sweat sodium concentration was $17 \mathrm{mmol} / 1$. The thyroid profile was normal. He was treated with prednisone $7.5 \mathrm{mg}$ every six hours but the jaundice persisted.

At six weeks he was transferred to the University Hospital of Wales. $\mathrm{He}$ was pale, feverish, and jaundiced with hepatomegaly but no splenomegaly. The urine was dark and stools pale but not completely colourless. Investigations showed: haemoglobin $11.9 \mathrm{~g} / \mathrm{dl}$, reticulocytes $3^{\prime \prime} \%$, platelets $699 \times 10^{9} / 1$, total bilirubin $85.5 \mu \mathrm{mol} / 1(5.0 \mathrm{mg} /$ $100 \mathrm{ml})$, conjugated bilirubin $17 \cdot 1 \mu \mathrm{mol} / 1(1 \mathrm{mg} / 100 \mathrm{ml})$, SGOT 126 IU/l, SGPT $158 \mathrm{IU} / 1$, and alkaline phosphatase $37 \mathrm{IU} / 1$. The urine contained no excess urobilinogen or bile salts. Serum immunoglobulins were normal. The Rose-Bengal excretion test showed that $18 "$." was excreted in 48 hours and $21.6 \%$ in 72 hours. Though excretion was impaired it was more than that usually found in biliary astresia. Hepatitis was diagnosed and no specific treatment was recommended.

At 12 months his general condition remained the same but with slight clinical improvement; hepatomegaly of $1 \mathrm{~cm}$ persisted and he had developed pruritus. Serum bilirubin concentration was $58 \mu \mathrm{mol} / \mathbf{l}$ $(3.4 \mathrm{mg} / 100 \mathrm{ml})$, SGOT $274 \mathrm{IU} / \mathrm{l}$, alkaline phosphatase >150 IU/l, haemoglobin $10 \cdot 1 \mathrm{~g} / \mathrm{dl}$, and reticulocyte count $4 \%$. Oral iron treatment was begun and the haemoglobin rose to $11.0 \mathrm{~g} / \mathrm{dl}$. Because of the persistent jaundice laparotomy was considered for liver biopsy and the exclusion of biliary obstruction.

At 16 months, before laparotomy, several investigations were performed. Ultrasonic scan showed a normal gall bladder. Serum bilirubin concentration was $80.3 \mu \mathrm{mol} / 1(4.7 \mathrm{mg} / 100 \mathrm{ml})$, SGOT 247 $\mathrm{IU} / \mathrm{l}$, and alkaline phosphatase $160 \mathrm{IU} / 1$. Blood urea and electrolytes were normal. Tests for hepatitis-associated antigen and antibody 